\title{
Seaweed and slope sediment prospecting, Mârmorilik area, central West Greenland
}

\section{H. R. Cooke}

This work was to prospect for base metal deposits by geochemical analysis of the metal content in seaweed and in slope sediments. Previous sampling (Bollingberg, 1975; Vandkvalitetsinstituttet, 1972; Grønlands Fiskeriundersøgelser et al. 1974; GGU et al. 1975, 1976) showed that lead and zinc in seaweed (Fucus vesiculosis, F. distichus) near the mill tailings outlet and mining in the Mârmorilik area had increased from a few parts per million to $100+\mathrm{ppm} \mathrm{Pb}$ and $200+\mathrm{ppm} \mathrm{Zn}$.

The Mârmorilik area is particularly suitable for such prospecting because three $\mathrm{Pb}-\mathrm{Zn}$ deposits - Sorte Engel, Agpat, and Uvkusigssat - afford known controls for testing metal variation in the seaweed and sediments. It was hoped that new metal deposits might be localised by their presumably similar anomalous geochemical response in seaweed and sediments.

The locations of the samples are shown in fig. 8, together with the cold extraction analyses of the sediments. The seaweed has not yet been analysed.

\section{Field work}

The sampling was done from Agpat to Mârmorilik during 11th-14th July, 1977, from the boat Petra, hired from Hans Mathiassen of Sâtut. About $200 \mathrm{~km}$ were sailed, during which 33 samples of seaweed and 15 slope or run-off stream sediments were collected.

The intention was to run cold extraction heavy metal analyses on the samples aboard the boat during the field work, to obtain feedback to guide further prospecting (Cooke, 1976; Kunzendorf \& Cooke, 1977). However, this was not practical for several reasons:

(a) Lack of space, especially a clean working place,

(b) Unsettled, windy weather and waves precluding analytical work on deck,

Fig. 8. Location of samples tested by cold extraction analysis. Numbers indicate millilitres of dithizone solution needed to neutralise metal dissolved from the sample.

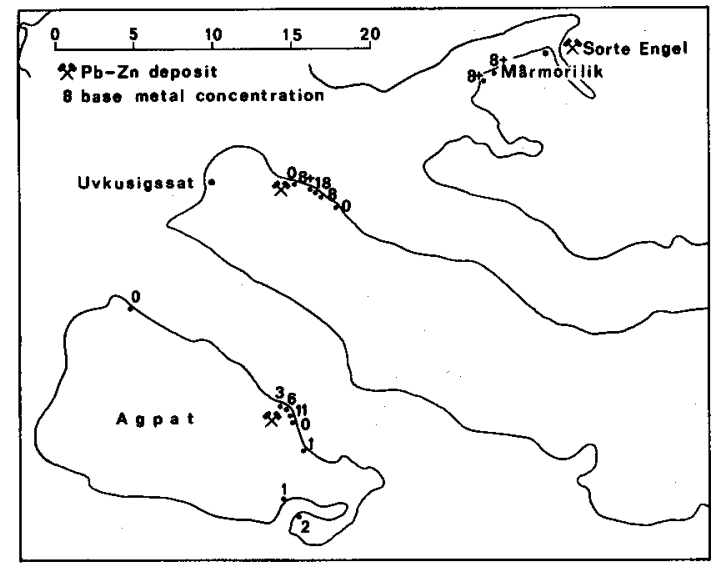


(c) Insufficient time to do analyses and also keep up with the sampling,

(d) The boat was hired full-time and from an economic point of view no unnecessary delays in the sampling could be afforded.

The samples were therefore bagged and stored. After the field work, while in Søndre Strømfjord in transit it was possible to dry the seaweed samples, and to run all the sediment samples with cold extraction analysis. One seaweed sample was run but this took several hours to ash on an Optimus camp stove with our limited equipment. The rest were sent directly to Copenhagen for analysis.

\section{Preliminary results}

In the field, the seaweed growth showed a marked decrease near Mârmorilik. Whereas the thalli are normally $15-50 \mathrm{~cm}$ long, at the Mârmorilik tailings outlet they were only $2-4 \mathrm{~cm}$ long. Pending chemical analyses, however, nothing is known of their metal content.

The cold extraction analyses of the sediments are shown in fig. 8. In this test the sample is dropped in a solution of ammonium citrate and dithizone and shaken for 15 seconds. Metal dissolved from the sample changes the colour of the standard green dithizone solution, making it light blue, indigo, purple, pink, and finally red, with increasing amounts of metal. To measure the dissolved metal content, dithizone is added to the sample solution until the colour is brought back to end-point blue-green. The more dithizone needed, the more dissolved metal is indicated (Cooke, 1976).

All tests were carried out to end-point blue-green except the three $8+\mathrm{ml}$ tests, which were stopped at purple to pink colour. The samples are too few and scattered to reliably indicate correlations, but the more anomalous responses clearly cluster near the three known $\mathrm{Pb}-\mathrm{Zn}$ deposits.

\section{Acknowledgements}

Gunnar Ersgaard ably assisted in the sampling. Greenex kindly gave us accommodation on July 14th and 15th, and transport to Søndre Strømfjord in their chartered helicopter. The GGU group at Søndre Strømfjord loaned us working space and helped us set up for analysis.

\section{References}

Bollingberg, H. J. 1975: Geochemical prospecting using seaweed, shellfish and fish. Geochim. Cosmochim. Acta 39, 1567-1570.

Cooke, H. R. 1976: Geochemical prospecting at Mesters Vig, central East Greenland and at Mârmorilik, central West Greenland. Rapp. Grønlands geol. Unders. 80, 1.16-120.

GGU et al. 1975: Recipientundersøgelse 1974, Agfardlikavsâ, Qaumarujuk. 108 pp. Copenhagen.

GGU et al. 1976: Recipientundersøgelse 1975/1976, Agfardlikavsâ, Qaumarujuk. 113 pp. Copenhagen.

Grønlands Fiskeriundersøgelser et al. 1974: Recipientundersøgelse af Qaumarujuk Fjord og Agfardlikavsâ. July - August 1973. 169 pp. Copenhagen.

Kunzendorf, H. \& Cooke, H. R. 1977: Follow-up work in the Kap Franklin and the Høgboms Bjerg area, northern East Greenland, 1976. Risø Electronics Dept., Int. unpubl. rep., 26 pp.

Vandkvalitetsinstituttet 1972: Recipientundersøgelse af Qaumarujuk Fjord - Agfardlikavsâ, August 1972. 110 pp. Copenhagen. 